\title{
Pseudoisolationism: the Neoimperialism of the State(s)
}

\author{
James T. Slaven ${ }^{1}$ \\ ${ }^{1}$ Department of History, Dalhousie University, Halifax, Nova Scotia \\ Correspondence: James T. Slaven, Department of History, Dalhousie University, Halifax, Nova Scotia.
}

Received: January 7, 2019

doi:10.11114/ijsss.v7i4.4353
Accepted: June 17, $2019 \quad$ Available online: June 27, 2019

URL: https://doi.org/10.11114/ijsss.v7i4.4353

\begin{abstract}
During the Obama administration years, the American military seemed to be withdrawing and American global hegemony withering. The administration had adopted a new foreign policy doctrine called "offshore balancing," and its critics were many, dubbing the doctrine "neoisolationist." However, this label has misdiagnosed the doctrine, which as this essay will first argue, can more accurately be labeled "pseudoneoisolationist" - the American military may have withdrawn its conventional forces to a degree, but it continues to become increasingly reliant on unmanned combat aerial vehicles (UCAVs). These UCAVs have allowed the United States to maintain Pax Americana while appearing to have staged a global retreat. This essay will then argue that two aspects of the American drone program have redefined territoriality: targeting methods and legal justification. This redefinition is a neoimperialist understanding, although admittedly it is one that cannot be correctly categorized as imperialist nor neoimperialist based on their traditional definitions. Finally, this essay will discuss why it is important to discuss the first two subjects (i.e. offshore balancing and the American drone program's redefinition of territoriality) together, rather than in isolation.
\end{abstract}

Keywords: Offshore Balancing, United States, Neoimperialism, Neoisolationism, Drones, Territoriality, UCAV, Pseudoneoisolationism

\section{Introduction}

During the Obama administration years, the American military seemed to be withdrawing and American global hegemony withering. The administration had adopted a new foreign policy doctrine called "offshore balancing," and its critics were many, dubbing the doctrine "neoisolationist." However, this label has misdiagnosed the doctrine, which as this essay will first argue, can more accurately be labeled "pseudoneoisolationist" - the American military may have withdrawn its conventional forces to a degree, but it continues to become increasingly reliant on unmanned combat aerial vehicles (UCAVs). These UCAVs have allowed the United States to maintain Pax Americana while appearing to have staged a global retreat. This essay will then argue that two aspects of the American drone program have redefined territoriality: targeting methods and legal justification. This redefinition is a neoimperialist understanding, although admittedly it is one that cannot be correctly categorized as imperialist nor neoimperialist based on their traditional definitions. Finally, this essay will discuss why it is important to discuss the first two subjects (i.e. offshore balancing and the American drone program's redefinition of territoriality) together, rather than in isolation.

\section{Literature Review}

In Calling 911: geopolitics, security and America's New War (2003), Simon Dalby outlined American imperialism after 9/11 and how it became the standard for a new kind of imperial warfare. He argued that in the aftermath of 9/11, the United States struggled to understand that classical European geopolitics, where "mutually exclusive spatial entities" conflicted with one another, were no longer predominant (Dalby, 2003, p. 74, 82). In other words, without a clearly defined (i.e. territorially defined) enemy to confront, the American military reaction was left searching for a target (Dalby, 2003, p. 72). Subsequently, the United States used its military to invade and occupy, or otherwise simply to garrison, foreign territory in an attempt to neutralize threats to its national security (i.e. under the guise of self-defence; Dalby, 2003, p. 80). As this essay will later argue and as Dalby argued, despite the United States neglecting to "conquer, annex, or fundamentally remake" these territories (as would be expected of true classical imperialism), it has and continues to colonize these territories via new technologies, and thus its anti-imperial national identity is only surface level deep (Dalby, 2003, p. 82). 
In From a View to Kill: Drones and Late Modern Warfare (2011), Derek Gregory described how modern warfare, conducted virtually through drones, has changed the very conception of battlespace, itself (p. 190). He argued that from the viewpoint of the American drone program modern battlespace has expanded across the world. This virtual, globalized battlespace results in a new version of (American) imperialism that can be remotely enforced (Gregory, 2011, pp. 189-90). In other words, the virtual application of violent force has caused "time-space compression" which means that the American military can theoretically exercise violence everywhere and at all times, as this essay will later elaborate (Gregory, 2011, p. 192).

In Mastering Space: Hegemony, Territory and International Political Economy (1995), John Agnew similarly described how emerging technologies had the potential to change how states interact with space. Rather than colonizing space by controlling a place(s) "on the ground," new technologies allow states to colonize space by controlling it virtually, thereby controlling all places (Agnew, 1995, pp. 95-6). In other words, by controlling space virtually states can control space instantaneously, forgoing the traditional needs of an empire to establish and maintain physical control over a place via a physical presence. It is from the theoretical starting points of Dalby, Gregory, and Agnew that this essay will now begin.

\section{Offshore Balancing}

Before exploring the neoimperialist reality of American offshore balancing, this essay will first briefly discuss what exactly offshore balancing as a foreign policy entails. By 2011, offshore balancing had been named by Newsweek as the Obama administration's foreign policy doctrine (Beinart, 2011). By 2016, John J. Mearsheimer and Stephen M. Walt had published the definitive work on offshore balancing titled "The Case for Offshore Balancing: A Superior U.S. Grand Strategy." Primarily evidenced by Obama's withdrawal of troops from Afghanistan and Iraq, as well as his later infamous "Red Line" failure in Syria, offshore balancing (as the name suggests) is primarily characterized by, "eschewing social engineering and minimizing the United States' military footprint... The United States would maintain substantial naval and air assets and modest but capable ground forces" (Mearsheimer \& Walt, 2016, p. 74, 80). The doctrine also advocates: (1) buckpassing regional defence to smaller allies in order to check the rise of a potential hegemon; (2) minimizing the threat of anti-American terrorism by "respecting the sovereignty of other states"; (3) strengthening the American economy by reducing its military expenditures as a result of, in turn, reducing the level of troops the United States garrisons abroad (Mearsheimer \& Walt, 2016, pp. 83-4, 87-8).

Subsequently, the former president's foreign policy doctrine was dubbed in newspaper headlines and book titles: "Retreating Ashore," or America in Retreat (Hoffman, 2016; Rose, 2015). Critics of offshore balancing warned that this "neoisolationist" doctrine threatened America's global hegemony (Roskin, 2016, p. 7). Rather than conserving American economic and military strength in order to maintain the current balance of power (i.e. Pax Americana) by "husbanding military strength," American armed forces would require massive re-expansion, and therefore massive expenditure, when the United States is inevitably pulled into a conflict to check the rise of a regional power (Mearsheimer \& Walt, 2016, p. 82). Bret Stephens (2014), in America in Retreat, argues that: "Barack Obama offered a blueprint for a new foreign policy, demanding a smaller U.S. footprint in the world" (p. 67). However, these criticisms represent a flawed understanding of the doctrine and have misidentified it as some kind of "neoisolationism," when in fact there is no evidence of a global American retreat.

Having discussed offshore balancing as a foreign policy, in theory, and its critiques, this essay will now examine the reality of offshore balancing. Neoisolationism, as has been discussed above, would mean a divergence from the Pax Americana status quo and therefore would entail some sort of global American 'retreat.' Although the world has indeed seen a gradual withdrawal of American troops from its vested regional interests, the American military presence has not withdrawn on a global scale. In other words, although there are literally fewer American "boots on the ground," the American military footprint has not changed - in fact, there's an argument to be made that it has actually increased. Shima Keene (2015) notes in Lethal and Legal: the Ethics of Drone Strikes, as of 2012, "the Pentagon was reported to have 7,000 drones under its control, representing approximately one-third of all U.S. military aircraft" (p. 1). Evidently, as the United States adopts offshore balancing more heartily, and the American military transitions to forces capable of exerting "over-the-horizon" pressure (i.e. air and naval forces), unmanned combat aerial vehicles play an increasingly large role (Allin \& Jones, 2012, p. 89). Approximately 10 times more drone strikes were authorized under the Obama administration than under the George W. Bush administration-506 drone strikes compared to 50 drone strikes, respectively (Zenko, 2016). As Ian Shaw notes in Predator Empire: Drone Warfare and Full Spectrum Dominance: "by 2013, around 95 percent of the US non-battlefield targeted killings were conducted by drones" (Shaw, 2016, p. 113). Furthermore, as Medea Benjamin (2017) writes for The Guardian, by 2016 the United States maintained a military presence in " $70 \%$ of the world's nations, 138 countries - a staggering jump of $130 \%$ since the days of the Bush administration." Clearly, there is no evidence of "America in Retreat," and instead it would be more accurate to conclude that there is evidence of a sustained (if not, increased) level of American presence and intervention abroad. 
Furthermore, Mearsheimer and Walt's "The Case for Offshore Balancing: A Superior U.S. Grand Strategy" fails to mention UCAVs, even though it was written in 2016 (i.e. towards the end of the Obama administration years) when drone warfare had been well-established as both the new American modus operandi and as President Obama's legacy (Kaufman, 2018; Monbiot, 2012; Zenko, 2016). Although the authors of "The Case for Offshore Balancing" have apparently forgotten to mention the role of the drone program in contemporary foreign policy and military interventions, their critics are just as equally at fault for, by and large, having neglected to mention it. As Shaw clarifies: "as U.S. military technology has become more sophisticated, the significance of mass, force, and territoriality has shrunk (although by no means disappeared)" (Shaw, 2016, p. 132). So, as this essay has discussed thus far, despite the appearance of a "global American retreat" when measuring in terms of conventional military forces, the reality of the maintenance of a global, American military presence when measured in UCAVs is evident. Offshore balancing has been misdiagnosed as "neoisolationism," when in fact it merely appears that way, and it can therefore correctly be labelled pseudoneoisolationism.

\section{The Drone Program: Redefining Territoriality}

This essay will now proceed to argue that the American, neoimperialist redefinition of territoriality can be examined, specifically, by looking at the targeting methods used in the drone program and the legality of drone warfare under international law.

Strikes carried out under the American drone program are (theoretically) authorized using two sets of targeting methods: personality strikes and signature strikes. The targeted killing of individuals through both personality and signature strikes redefines the American state's understanding of territoriality, although signature strikes have much more profound implications, as will be discussed. As Shima Keene (2015) describes in "Lethal and Legal: The Ethics of Drone Strikes," personality strikes are situations wherein: "an individual whose identity is known is specifically targeted" (p. 24). However, signature strikes are situations wherein, as Keene (2015) once again clarifies:

Unknown individuals often in groups are targeted... the precise identity of these individuals is unknown, [and therefore] the individuals targeted must match a pre-identified 'signature' of behaviour that the United States links to militant activity or association... patterns of behaviour are used to determine a target. (p. 25)

Simply put, the United States does not know who it is killing in these signature strikes. However, as Keene emphasized in the quote above, it may be worth restating that: the United States does not know precisely who it is killing. So then, a more convincing argument might be made by investigating the "signatures" or patterns of behaviour that the United States sets out in signature strike targeting methods. However, upon investigation, what are considered signatures of terrorist behaviour have, as Keene (2015) puts it, "come under criticism" (p. 25). Greg Miller and Bob Woodward (2013) describe multiple strikes based on circumstantial evidence in "Secret memos reveal explicit nature of U.S., Pakistan agreement on drones":

On March 23, 2010, the CIA launched missiles at a "person of interest" in a suspected al-Qaeda compound. The man caught the agency's attention after he had "held two in-car meetings, and swapped vehicles three times along the way." Other accounts describe militants targeted because of the extent of "deference" they were shown when arriving at a suspect site.

Keene (2015) cites in her own work one instance when: "on February 21, 2010, 23 Afghan civilians were wrongly identified by a U.S. operated drone as enemy combatants and killed in airstrikes" (p. 27). Clearly then, it is not an oversimplification, after all, to say that the United States does not know who it is killing in these strikes. Shaw (2016) starkly notes: "if the pattern of life [emphasis added] is marked as a threat to national security, it can be eliminated" (p. 128).

By examining drone strike targeting methods and their consequences, it becomes clear that the United States is engaged in a new kind of neoimperialist exercise. Specifically, by extrajudiciously killing individuals or groups of individuals through signature strike targeting methods the American state is exercising legal authority over non-citizens. Furthermore, the American state is exercising legal authority over a specific demographic (theoretically, this is military-age males) of a non-citizen population within a bounded geographic space (i.e. another state), rather than exercising legal authority over the whole population. On top of that, the individuals that belong to that particular demographic have no notice that they are under American law, unlike classical, imperialist occupations, because the American state subjectively determines whether or not certain "patterns of life" are a threat to national security (Keene, 2015, p. 27; Shaw, 2016, p. 128). At that point, whether or not the targeted individual(s) is known for certain to be a threat to national security (i.e. a terrorist), the individual is killed, and the right to surrender and defend themselves in a court of law is withheld (also known as extrajudicial killing; Keene, 2015, p. 12). So, by continuing to authorize drone 
strikes based on signature strike targeting methods, the American state is claiming and exercising legal authority over a specific demographic of non-citizens within a separate bounded geographic space (i.e. another state).

Similar to the targeting methods used for authorizing drone strikes, the legality of drone strikes under international law has equally profound implications for territoriality. The United States has consistently harkened back to the September 11 th terrorist attacks as the justification needed for targeted killings carried out under the drone program, and within the context of the Global War on Terror (GWOT) more generally. On September 12, 2001 the United Nations Security Council unanimously adopted Resolution 1368 which, while denouncing the September 11 terrorist attacks, recognized, "the inherent right of individual or collective self-defence in accordance with the Charter [of the United Nations]," referring to the right to self-defence as laid out in Article 51 of the Charter (United Nations Security Council, 2001; Anghie, 1996, 276). The United States specifically cites this right to self-defence as the legal basis for targeted killings (Keene, 2015, p. 16; see also Vavrichek, 2014, p. 32). However, the the legal basis for targeted killings also lies in equal part within International Human Rights Law (IHRL). As Diane Vavrichek (2014) notes in "The Future of Drone Strikes: A Framework for Analyzing Policy Options," IHRL states that lethal force may only be used against individuals who pose an "imminent [emphasis added] and substantial threat to life" (pp. 34-5). However, Vavrichek (2014) then goes on to cite a Department of Justice legal memo which, "concludes that, "the condition that an operational leader present an "imminent" threat of violent attack against the United States does not require the United States to have clear evidence that a specific attack on U.S. persons and interests will take place in the immediate future' “(p. 37).

This legal basis, grounded in the UNSC Resolution 1368 as well as IHRL, is precisely where the United States redefines its definition of territoriality. This neoimperialist redefinition relies on two concepts which it borrows from the UNSC Resolution 1368 and IHRL, respectively: self-defence and imminence. As Vavrichek (2014) notes:

This usage is at odds with the definition of the word "imminent" and signals a departure from the historical criteria for a nation to act preemptively in self-defence only when the "necessity of that self-defence is instant, overwhelming, and leaving no choice of means, and no moment of deliberation." (p. 37)

Similarly, Antony Anghie (1996), in Imperialism, Sovereignty, and the Making of International Law, argues that "the doctrine of pre-emptive self-defence... appears to extend the concept of self-defence well beyond traditionally understood boundaries of Article 51 of the UN Charter" (p. 276). This "historical departure" also signals a departure from traditional understandings of territoriality. By preemptively defending itself against individuals using signature strike targeting methods and therefore by understanding that those individuals pose an imminent threat to national security regardless of whether or not those individuals can practically reach American territory (i.e. the continental United States) in the immediate future, the United States is implying that American territory is no longer restricted by linear boundaries and traditional notions of territoriality, but instead has spread across the globe. It is only through this understanding that the American drone program is legally authorized to strike anywhere in the world since an individual in Afghanistan, Iraq, or Yemen, to offer up historical examples, can pose an imminent threat to American national security and therefore require preemptive actions in the name of self-defence.

\section{Connecting the Dots}

This essay will now discuss the importance of discussing offshore balancing and the American, neoimperialist redefinition of territoriality in an effort to make it clear that not only is offshore balancing pseudoneoisolationist, but it is actually neoimperialist.

In summary, it is important to discuss offshore balancing in tandem with the American drone program and its implications for territoriality because it becomes clear that it constitutes a dangerously attractive foreign policy option for politicians, and yet it still has not been properly identified as a neoimperialist doctrine. It would not be enough to discuss offshore balancing as a foreign policy and the neoimperialist redefinition of territoriality occurring under the American drone program, separately because that would be a failure to realize the neoimperialist reality of the current American foreign policy doctrine. By adhering to offshore balancing as a doctrine, the American military will suffer fewer casualties by relying more on UCAVs, which results in minimal domestic backlash, while maintaining American global hegemony (Bahador \& Walker, 2012, pp. 248-9). Furthermore, it is a self-perpetuating foreign policy: public perception of the United States worsens inside the state(s) that the American drone program operates in, resentment builds among the populace, and, conversely, support for terrorist organizations grows (albeit, amongst a small percentage of the populace; Shah, 2010, pp. 86-7). Eventually this leads to a terrorist attack abroad, perhaps even within the United States (although it is difficult to discern how many terrorist attacks have occurred within the continental United States since 2001 since there is little consensus about what constitutes a terrorist attack), at which point there is a public outcry of support for military action and, potentially, support from the heads of allied states. As a result, the United States then has all the 
justification and support it needs to continue its drone program, and the self-perpetuating cycle begins, as Robert Kaplan (2015), in Imperial Grunts, puts it in his own words: "terrorism was both a cause and a symptom [of the GWOT]" (p. 7). Hall Gardner (2005) describes the same process in American Global Strategy and the "War on Terrorism":

State leaderships additionally use the threat of external terror (threats coming from outside the state) in order to obtain and sustain both allegiance and obedience, and to repress dissent. In The Politics, Aristotle argued that "the distant fear must be brought home" - in that [political] elites seek to preserve their power and influence and obtain both domestic and international allegiance to their goals by manipulating real and imagined (or exaggerated) fears that their 'constitutions' and basic freedoms might be subverted by enemies abroad. (p. 54)

This dangerous, violent, cyclical misunderstanding is in part driven by a discourse based in the dichotomy of good and evil, as Bret Stephens (2014), himself, writes in America in Retreat (which was mentioned at the beginning of this paper):

America needs to be the world's policeman... Cops merely walk the beat, reassuring the good, deterring the tempted, punishing the wicked... It is done because it has to be and there's no one else to do it, and because the benefits of doing it accrue not only to those we protect but also, indeed mainly, to ourselves. (pp. xv-i)

This, of course, is a vast over-simplification of American foreign policy and ignores entirely the cyclical violence that is perpetuated by American foreign policy particularly within the context of the GWOT, as discussed above. However, to elaborate further would verge on overextending this essay's core argument. Rather, it should simply be stated that: the connection must be made between offshore balancing as a foreign policy and the implications of the drone program for American territoriality so that the present, neoimperialist reality of American foreign policy can be properly identified and understood as neoimperialist.

\section{What Now?}

In conclusion, this essay has discussed offshore balancing as a foreign policy doctrine, how it has incorrectly been labeled "neoisolationist," and why pseudoneoisolationist would be a more suitable label. Then, the American drone program and its neoimperialist redefinition of territoriality through two aspects - targeting methods and legal justification-was discussed. Finally, it has been argued that these two subjects need to be examined together so that the neoimperialist reality of American foreign policy, perpetuated by the American drone program, can be properly identified as such. So, what now? Various scholars, such as Anghie (1996), are describing the emergence of a "new imperialism" (p. 274). Some, such as Robert Cooper, are even advocating for a kind of " 'defensive imperialism... a new kind of imperialism, one acceptable to a world of human rights and cosmopolitan values.' " (as cited in Anghie, 1996, p. 274). Nevertheless, it has become increasingly clear that contemporary understandings of neoimperialism also need to be broadened in the wake of this new military technology_UCAVs_-because, as this essay has discussed, they allow the United States to carry out a foreign policy that cannot be correctly labeled as imperialist nor neoimperialist (at least, not by the current parameters of either definition). Therefore, this essay suggests a new definition of neoimperialism be outlined to include the territorial implications created by the American drone program. With this expanded definition of neoimperialism, then offshore balancing, as a foreign policy, may correctly be identified by its true nature- not neoisolationist, but neoimperialist.

\section{References}

Agnew, J., \& Corbridge, S. (1995). Mastering space : Hegemony, territory and international political economy. London ; New York: Routledge.

Allin, D., \& Jones, E. (2012). Weary policeman : American power in an age of austerity (Adelphi (Series) (International Institute for Strategic Studies) ; 430-431). London: International Institute for Strategic Studies : Routledge.

Anghie, A. (2005). Imperialism, sovereignty, and the making of international law (Cambridge studies in international and comparative law (Cambridge, England: 1996)). Cambridge, UK; New York: Cambridge University Press.

Bahador, B., \& Walker, S. (2012). Did the Iraq War Have a Body Bag Effect? American Review of Politics, $33,247$. https://doi.org/10.15763/issn.2374-7781.2012.33.0.247-270

Beinart, P. (2011). Obama's Foreign Policy Doctrine Finally Emerges With 'Offshore Balancing'. Newsweek Web Exclusives, p. Newsweek Web Exclusives, Nov 28, 2011.

Benjamin, M. (2017, January 9). America dropped 26,171 bombs in 2016. What a bloody end to Obama's reign. The Guardian. Retrieved from 
https://www.theguardian.com/commentisfree/2017/jan/09/america-dropped-26171-bombs-2016-obama-legacy

Dalby, S. (2003). Calling 911: Geopolitics, security and America's new war. Geopolitics, 8(3), 61-86. https://doi.org/10.1080/14650040412331307712

Gardner, H. (2005). American global strategy and the "War on Terrorism". Aldershot, Hampshire, England ; Burlington, VT: Ashgate.

Gregory, D. (2011). From a View to a Kill: Drones and Late Modern War. Theory, Culture \& Society, 28(7-8), 188-215. https://doi.org/10.1177/0263276411423027

Hoffman, F. (2016). Retreating Ashore: The Flaws of Offshore Balancing. Retrieved from https://www.fpri.org/2016/07/retreating-ashore-flaws-offshore-balancing/

Kaplan, R. (2005). Imperial grunts : The American military on the ground. New York: Random House.

Kaufman, B. M. (2018, September 17). Trump is unshackling America's drones thanks to Obama's weakness. The Guardian. Retrieved from

https://www.theguardian.com/commentisfree/2018/sep/17/the-cia-is-back-in-the-drone-business-trump-is-unshackl ing-americas-drones-thanks-to-obamas-weakness.

Keene, S., \& Army War College. Strategic Studies Institute, publisher. (2015). Lethal and legal? : The ethics of drone strikes. Carlisle Barracks, PA: Strategic Studies Institute and U.S. Army War College Press.

Mearsheimer, J., \& Walt, S. (2016). The Case for Offshore Balancing: A Superior U.S. Grand Strategy. Foreign Affairs, 95(4), 70-83.

Miller, G., \& Woodward, B. (2013, October 24). Secret memos reveal explicit nature of U.S., Pakistan agreement on drones. The Washington Post. Retrieved from

https://www.washingtonpost.com/world/national-security/top-pakistani-leaders-secretly-backed-cia-drone-campaig n-secret-documents-show/2013/10/23/15e6b0d8-3beb-11e3-b6a9-da62c264f40e_story.html?utm_term=.6b44836a $4 \mathrm{~b} 08$

Monbiot, G. (2012, December 17). In the US, mass child killings are tragedies. In Pakistan, mere bug splats. The Guardian. Retrieved from https://www.theguardian.com/commentisfree/2012/dec/17/us-killings-tragedies-pakistan-bug-splats

Rose, G. (n.d.). America in Retreat: The New Isolationism and the Coming Global Disorder. Retrieved from https://www.foreignaffairs.com/reviews/america-retreat-new-isolationism-and-coming-global-disorder

Roskin, M. (2016). Rebalancing Offshore Balancing. Parameters, 46(3), 7-11.

Shah, S. A. (2010). War on terrorism: Self defense, operation enduring freedom, and the legality of U.S. drone attacks in Pakistan. Washington University Global Studies Law Review, 9(1).

Shaw, I. G. R. (2016). Predator empire : Drone warfare and full spectrum dominance. Minneapolis: University of Minnesota Press. https://doi.org/10.5749/minnesota/9780816694730.001.0001

Stephens, B. (2014). America in retreat: The new isolationism and the coming global disorder. New York, New York: Sentinel.

United Nations Security Council. (2001, September 12). Security Council Condemns, 'In Strongest Terms,' Terrorist Attacks On United States. Retrieved from https://www.un.org/press/en/2001/SC7143.doc.htm

Vavrichek, D. M., \& US Dept of the Navy; CENTER FOR NAVAL ANALYSES ALEXANDRIA VA. (2014). The Future of Drone Strikes: A Framework for Analyzing Policy Options. https://doi.org/10.21236/ADA609402

Zenko, M. (2016, January 12). Obama's Embrace of Drone Strikes Will Be a Lasting Legacy. The New York Times. Retrieved from https://www.nytimes.com/roomfordebate/2016/01/12/reflecting-on-obamas-presidency/obamas-embrace-of-dronestrikes-will-be-a-lasting-legacy

\section{Copyrights}

Copyright for this article is retained by the author(s), with first publication rights granted to the journal.

This is an open-access article distributed under the terms and conditions of the Creative Commons Attribution license which permits unrestricted use, distribution, and reproduction in any medium, provided the original work is properly cited. 